\title{
Removal color from Palm Oil Mill Effluent (POME): Electrocoagulation Method vs Microfiltration using Nanofiber Membrane
}

\author{
Muhammad Syaamil Saad ${ }^{1}$, Mohd Dzul Hakim Wirzal ${ }^{1, *}$, Nur Syakinah Abd Halim ${ }^{1}$ and Mohammad \\ Rizwan Khan ${ }^{2}$ \\ ${ }^{1}$ Chemical Engineering Department, Universiti Teknologi PETRONAS, 32610 Bandar Seri Iskandar, \\ Perak, Malaysia \\ ${ }^{2}$ Chemistry Department, College of Science, King Saud University, Riyadh 11451 Saudi Arabia \\ *E-mail: mdzulhakim.wirzal@utp.edu.my
}

doi: $10.20964 / 2020.11 .08$

Received: 12 July 2020 / Accepted: 25 August 2020 / Published: 30 September 2020

\begin{abstract}
Palm oil trees have long been introduced in Malaysia since before the establishment of the country. Nowadays, Malaysia is known as the second major exporter of palm oil and palm-based products, which totals up to 17.95 million tonnes of oils and fats around the globe in 2017. However, the rapid growth of palm oil plantation led to the increment of wastewater due to palm oil processing. Hence, various methods for treatment of palm oil mill effluent (POME) were implemented. In this study, two methods were chosen namely electrocoagulation and microfiltration. In electrocoagulation method, $2 \mathrm{~V}$ to $10 \mathrm{~V}$ of potential difference were applied with iron as electrode while for microfiltration, nylon 6,6 nanofiber membrane was used and were fabricated using electrospinning method. The results show that by using electrocoagulation method, $94.2 \%$ removal of color was observed for $10 \mathrm{~V}$ and $13.4 \%$ for $2 \mathrm{~V}$ while for microfiltration, $13.5 \%$ was obtained. Chemical oxygen demand (COD) reduction using electrocoagulation method was observed to be higher with $69.9 \%$ reduction for $10 \mathrm{~V}$ while for microfiltration, $68.5 \%$ COD reduction was recorded. Hence, electrocoagulation is seen to be more efficient in treating palm oil-based wastewater compared to microfiltration.
\end{abstract}

Keywords: palm oil; effluent; electrocoagulation; microfiltration; nanofiber

\section{FULL TEXT}

(C) 2020 The Authors. Published by ESG (www.electrochemsci.org). This article is an open access article distributed under the terms and conditions of the Creative Commons Attribution license (http://creativecommons.org/licenses/by/4.0/). 